\title{
Effects of mitochondrial inhibition by chloramphenicol on the mitotic cycle of human cell cultures
}

\author{
URSULA MITTWOCH, D. J. KIRK, and D. WILKIE \\ Departments of Human Genetics and Microbiology, University College London
}

\begin{abstract}
Summary. Chloramphenicol, at concentrations of $500 \mu \mathrm{g} / \mathrm{ml}$, had a marked inhibitory effect on mitoses in human fibroblasts. Metaphase and G2 appeared to be particularly sensitive to the action of the drug. With concentrations of 1000 $\mu \mathrm{g} / \mathrm{ml}$, or with $500 \mu \mathrm{g} / \mathrm{ml}$ after prolonged exposure, the cells did not reach G2 and no mitoses were seen. The drug required several hours to produce its effect. Studies of oxygen uptake showed no immediate reduction in the respiratory activity of cells at concentrations of $500 \mu \mathrm{g} / \mathrm{ml}$ or $1000 \mu \mathrm{g} / \mathrm{ml}$ but cells which had been in contact with $500 \mu \mathrm{g} / \mathrm{ml}$ of drug for 24 hours showed a marked reduction in respiratory activity. Since the primary effect of chloramphenicol is arrest of mitochondrial protein synthesis, it is concluded that continued synthesis of mitochondrial proteins in the maintenance of the respiratory chain are prerequisites for normal cell division in fibroblasts.
\end{abstract}

Chloramphenicol is a causative agent of bone marrow dysfunction, which in severe cases leads to aplastic anaemia (Pisciotta, 1971). At the cellular level, the primary effect of the drug is to arrest the synthesis of mitochondrial protein by reacting with the mitochondrial ribosome (Grivell, Reijnders, and de Vries, 1971). At high concentrations it has been claimed that chloramphenicol may also inhibit oxidative phosphorylation and electron transport. Blockage of mitochondrial protein synthesis inhibits the formation of active cytochrome oxidase (Kroon and Jansen, 1968) and it is thought that as cells divide there will be a progressive loss of functional mitochondria, which in turn will affect ATP dependent processes, including cell maturation ( $c f$, Kroon and Arendzen, 1972). The question arises as to the rate of loss of functional mitochondria when replacement of the respiratory chain is precluded and attempts have been made to assess this in animals (Kroon, Gijzel, and Nijhoff, 1972).

In the experiments reported here, the effects of mitochondrial inhibition by chloramphenicol in cultures of human fibroblasts have been studied throughout the cell cycle with respect to nuclear DNA synthesis and mitosis. The results have been compared with those obtained with chlorimipramine, a direct inhibitor of mitochondrial function

Received 29 March 1974.
(Wilkie and Delhanty, 1970; Mittwoch and Wilkie, $\varnothing \vec{\varphi}$ 1971).

\section{Materials and methods}

Cell culture. Diploid human fibroblasts were de-? rived from skin biopsies from four normal adults (two males and two females) using standard techniques (Harnden, 1960) with modifications made by J. D. A. Delhanty in 1974 (personal communication). In this variation the minced biopsy fragments are immobilized on the bottom of a Leighton tube under pressure of a coverslip. The cells were grown in Eagle's minimum essential medium supplemented with hepes buffer, glutamine, and antibiotics (penicillin and streptomycin). Biopsy specimens were set up in this medium plus $20 \%$ fetal calf serum; in subsequent passages $10 \%$ fetal calf serum was used. Cells used in experiments had undergone 21 passages (experiment 1), six passages (experiment 2), 11 passages (experiment 3 ), 12 passages (experiment 4), and 11-12 passages (oxygen uptake).

Experimental procedures. For experiments 1-4 confluent cultures were trypsinized $(0.25 \%$ trypsin) and plated at concentrations of $10^{5}$ cells $/ \mathrm{ml}$ of medium into $30 \mathrm{~mm}$ Nunclon Petri dishes containing one coverslip each. Cells for experiments 1-3 were plated into medium containing $10 \%$ fetal serum, while for experiment $4,20 \%$ human serum was used. Chloramphenicol and chlorimipramine were dissolved in the appropriate medium before treatment of cells, and this was added by itself to control cells.

Cells were harvested by placing coverslips in $95 \%$ 
methanol, staining by the Feulgen reaction, and mounting in DPX. Mitoses were scored using an oil immersion objective. Partial synchronization following trypsinization resulted in a peak of mitoses approximately 38 hours after plating into $10 \%$ fetal calf serum and 32-34 hours after plating into $20 \%$ human serum.

Experiments were carried out as follows.

Experiment 1. Chloramphenicol was added 21 hours after plating at concentrations of 10,100 , and $1000 \mu \mathrm{g} / \mathrm{ml}$, respectively (see Tables $\mathrm{I}$ and II).

Experiment 2. $500 \mu \mathrm{g} / \mathrm{ml}$ of chloramphenicol was added at the time of plating, 4 hours after plating, and 19 hours after plating, respectively (see Tables III and IV).

Experiment 3. $500 \mu \mathrm{g} / \mathrm{ml}$ of chloramphenicol was added 26 hours after plating (see Tables V and VI).

Experiment 4. Chlorimipramine was added 17 hours after plating at concentrations of 5,10 , and $15 \mu \mathrm{g} / \mathrm{ml}$, respectively (see Tables VII and VIII).

Densitometry. DNA values of Feulgen-stained interphase nuclei were measured with a Barr and Stroud integrating microdensitometer. The readings were converted into logarithms to the base 2 and delineated into the three major DNA classes-2C, $4 \mathrm{C}$, and intermediate -as described previously (Mittwoch and Wilkie, 1971). Nuclei with the $2 \mathrm{C}$ amount of DNA were classed as G1, those with twice this amount as G2, while nuclei with intermediate values were regarded to be in the $S$ phase of DNA synthesis. A small proportion of cells had DNA values greater than $4 \mathrm{C}$ and these must have been polyploid.

Oxygen uptake. Oxygen uptake was measured polarographically in a Clarke type oxygen electrode. At least $6 \times 10^{6}$ cells in log phase (subcultured 2 days previously in $10 \%$ human serum in Eagle's MEM) were trypsinized in dilute $(0.025 \%)$ trypsin in Hank's balanced salt solution. The cells were derived from two different skin biopsies and had undergone 11-12 passages. In the experiment involving a 24-hour pretreatment with chloramphenicol the drug was included in both trypsin and Hank's solutions. Cells were introduced into the electrode well which contained $1 \mathrm{ml}$ Hank's solution. Chloramphenicol was added in aqueous solution. To arrest respiratory activity, $0.01 \mathrm{ml}$ of $0.1 \%$ potassium cyanide solution was added.

\section{Results}

DNA synthesis and mitosis. The effect of the drug is clearly dependent both on concentration and on the length of time during which the cells are exposed to it. It will be seen from Table I that $500 \mu \mathrm{g} / \mathrm{ml}$ of chloramphenicol after 15 hours' exposure caused a marked depression in the number of mitoses; in addition, the proportion of metaphases relative to other mitotic stages was significantly increased. The data suggest that an increase in metaphase index occurred also with lower doses of the drug. The data further suggest that the relative increase in metaphases is due to a shortage of prophases as well as one of ana- and telophases. The shortage of prophases in cultures treated with $500 \mu \mathrm{g} / \mathrm{ml}$ of drug is reflected in a high proportion of interphase cells in the G2 phase of the mitotic cycle (Table II). It seems, therefore, that at this concentration, chloramphenicol arrests cells in G2 after the completion of DNA synthesis; while those

TABLE I

NUMBERS OF MITOSES IN CELLS TREATED WITH DIFFERENT CONCENTRATIONS OF CHLORAMPHENICOL (drug added 21 hours after plating)

\begin{tabular}{|c|c|c|c|c|c|c|c|c|c|c|}
\hline \multirow{2}{*}{$\begin{array}{l}\text { Concentration } \\
\text { of Drug } \\
(\mu \mathrm{g} / \mathrm{ml})\end{array}$} & \multirow{2}{*}{$\begin{array}{l}\text { Duration } \\
\text { of Culture* } \\
(\mathrm{hr})\end{array}$} & \multirow{2}{*}{$\begin{array}{l}\text { Time in Contact } \\
\text { with Drug (hr) }\end{array}$} & \multirow{2}{*}{\multicolumn{2}{|c|}{$\begin{array}{l}\text { No. of Cells } \\
\text { Counted }\end{array}$}} & \multicolumn{4}{|c|}{ No. of Cells in } & \multirow{2}{*}{$\begin{array}{c}\text { Mitotic } \\
\text { Indext } \\
\left(0_{0}^{\circ}\right)\end{array}$} & \multirow{2}{*}{$\begin{array}{c}\text { Metaphase } \\
\text { Index } \\
\left(\begin{array}{c}0 \\
0\end{array}\right)\end{array}$} \\
\hline & & & & & $\begin{array}{l}\text { Pro- } \\
\text { phase }\end{array}$ & $\begin{array}{l}\text { Meta- } \\
\text { phase }\end{array}$ & $\begin{array}{l}\text { Ana- } \\
\text { phase }\end{array}$ & $\begin{array}{l}\text { Telo- } \\
\text { phase }\end{array}$ & & \\
\hline $\begin{array}{l}0 \\
0\end{array}$ & $\begin{array}{l}36 \\
38\end{array}$ & - & Total & $\begin{array}{l}2000 \\
2000 \\
4000\end{array}$ & $\begin{array}{l}11 \\
12 \\
23\end{array}$ & $\begin{array}{l}25 \\
13 \\
38\end{array}$ & $\begin{array}{l}5 \\
3 \\
8 \\
\end{array}$ & $\begin{array}{l}16 \\
17 \\
33\end{array}$ & $\begin{array}{l}2 \cdot 85 \\
2 \cdot 25\end{array}$ & 0.37 \\
\hline $\begin{array}{l}10 \\
10 \\
10\end{array}$ & $\begin{array}{l}36 \\
38 \\
40\end{array}$ & $\begin{array}{l}15 \\
17 \\
19\end{array}$ & Total & $\begin{array}{l}2000 \\
2000 \\
2000 \\
6000 \\
\end{array}$ & $\begin{array}{r}19 \\
8 \\
8 \\
35\end{array}$ & $\begin{array}{l}31 \\
13 \\
14 \\
58\end{array}$ & $\begin{array}{r}4 \\
3 \\
3 \\
10 \\
\end{array}$ & $\begin{array}{r}21 \\
7 \\
5 \\
33 \\
\end{array}$ & $\begin{array}{l}3 \cdot 75 \\
1 \cdot 55 \\
1 \cdot 50\end{array}$ & 0.43 \\
\hline $\begin{array}{l}100 \\
100 \\
100\end{array}$ & $\begin{array}{l}36 \\
38 \\
40\end{array}$ & $\begin{array}{l}15 \\
17 \\
19\end{array}$ & Total & $\begin{array}{l}2000 \\
2000 \\
2000 \\
6000 \\
\end{array}$ & $\begin{array}{r}5 \\
9 \\
7 \\
21 \\
\end{array}$ & $\begin{array}{l}40 \\
21 \\
15 \\
76\end{array}$ & $\begin{array}{l}2 \\
6 \\
1 \\
9\end{array}$ & $\begin{array}{r}18 \\
13 \\
9 \\
40\end{array}$ & $\begin{array}{l}3 \cdot 25 \\
2 \cdot 45 \\
1 \cdot 60\end{array}$ & 0.52 \\
\hline $\begin{array}{l}500 \\
500 \\
500\end{array}$ & $\begin{array}{l}36 \\
38 \\
40\end{array}$ & $\begin{array}{l}15 \\
17 \\
19\end{array}$ & Total & $\begin{array}{r}2000 \\
6000 \\
2000 \\
10,000 \\
\end{array}$ & $\begin{array}{l}4 \\
2 \\
2 \\
8\end{array}$ & $\begin{array}{r}1 \\
24 \\
2 \\
27 \\
\end{array}$ & $\begin{array}{l}0 \\
3 \\
0 \\
3\end{array}$ & $\begin{array}{l}0 \\
4 \\
1 \\
5\end{array}$ & $\begin{array}{l}0.25 \\
0.55 \\
0.25\end{array}$ & 0.63 \\
\hline $\begin{array}{l}1000 \\
1000 \\
1000\end{array}$ & $\begin{array}{l}36 \\
38 \\
40\end{array}$ & $\begin{array}{l}15 \\
17 \\
19\end{array}$ & Total & $\begin{array}{l}2000 \\
2000 \\
2000 \\
6000\end{array}$ & $\begin{array}{l}0 \\
0 \\
0 \\
0\end{array}$ & $\begin{array}{l}0 \\
0 \\
0 \\
0\end{array}$ & $\begin{array}{l}0 \\
0 \\
0 \\
0\end{array}$ & $\begin{array}{l}0 \\
0 \\
0 \\
0\end{array}$ & 0.00 & \\
\hline
\end{tabular}

* Time between plating and harvesting cells.

+ Proportion of mitoses among total number of cells.

¥ Proportion of metaphases among total number of mitoses. 
TABLE II

STAGES IN MITOTIC CYCLE IN INTERPHASE CELLS TREATED WITH DIFFERENT CONCENTRATIONS OF CHLORAMPHENICOL

\begin{tabular}{|c|c|c|c|c|c|c|c|}
\hline \multirow{2}{*}{$\begin{array}{l}\text { Concentration of Drug } \\
\left(\mu_{\mathrm{g}} / \mathrm{ml}\right)\end{array}$} & \multirow{2}{*}{$\begin{array}{l}\text { Duration of } \\
\text { Culture* (hr) }\end{array}$} & \multirow{2}{*}{$\begin{array}{l}\text { Time in Contact } \\
\text { with Drug (hr) }\end{array}$} & \multicolumn{4}{|c|}{ No. of Cellst in } & \multirow{2}{*}{ G2/Total } \\
\hline & & & G1 & $\mathbf{S}$ & G2 & Polyploidy & \\
\hline $\begin{array}{l}\mathbf{0} \\
\mathbf{0}\end{array}$ & $\begin{array}{l}15 \\
17\end{array}$ & $\begin{array}{l}36 \\
38\end{array}$ & 72 & 12 & 16 & 0 & $0 \cdot 16$ \\
\hline $\begin{array}{l}10 \\
10 \\
10\end{array}$ & $\begin{array}{l}15 \\
17 \\
19\end{array}$ & $\begin{array}{l}36 \\
38 \\
40\end{array}$ & 105 & 14 & 29 & 2 & $0 \cdot 19$ \\
\hline $\begin{array}{l}100 \\
100 \\
100\end{array}$ & $\begin{array}{l}15 \\
17 \\
19\end{array}$ & $\begin{array}{l}36 \\
38 \\
40 \\
\end{array}$ & 113 & 8 & 29 & 0 & $0 \cdot 19$ \\
\hline $\begin{array}{l}500 \\
500 \\
500\end{array}$ & $\begin{array}{l}15 \\
17 \\
19 \\
\end{array}$ & $\begin{array}{l}36 \\
38 \\
40 \\
\end{array}$ & 72 & 12 & 65 & 1 & 0.43 \\
\hline $\begin{array}{l}1000 \\
1000 \\
1000\end{array}$ & $\begin{array}{l}15 \\
17 \\
19\end{array}$ & $\begin{array}{l}36 \\
38 \\
40\end{array}$ & 89 & 41 & 19 & 1 & $0 \cdot 13$ \\
\hline
\end{tabular}

* Time between plating and harvesting cells.

† Fifty cells were measured from each culture; $G 1$ corresponds to $2 \mathrm{C}, \mathrm{G} 2$ to $4 \mathrm{C}, \mathrm{S}$ to intermediate values.

cells which enter mitosis may be further arrested in metaphase.

At the still higher dose of $1000 \mu \mathrm{g} / \mathrm{ml}$, DNA synthesis had not been completed (Table II) and there were no mitoses (Table I) at the end of the experiment.

When cells were plated in the presence of 500 $\mu \mathrm{g} / \mathrm{ml}$ of chloramphenicol, they became attached to the cover slips but there were no mitoses (Table III) nor was there any evidence of DNA synthesis (Table IV). The same result was obtained when the drug was added 4 hours after plating. When the drug was added 21 hours after plating, the results were similar to those shown in Tables I and II, ie, there was a low mitotic index with arrest of interphase cells in G2. Although in Table III the increase in metaphase index is insignificant, this may be due to the small numbers of mitoses in this experiment.

The results of adding chloramphenicol to cells only a few hours before mitosis are shown in Tables $\mathrm{V}$ and VI. A depression of mitotic index is not evident until 7 hours after the drug was added? when the number of prophases began to fall relative

TABLE III

NUMBER OF MITOSES IN CELLS TREATED WITH $500 \mathrm{\mu g} / \mathrm{ml}$ CHLORAMPHENICOL (drug added at different times after plating)

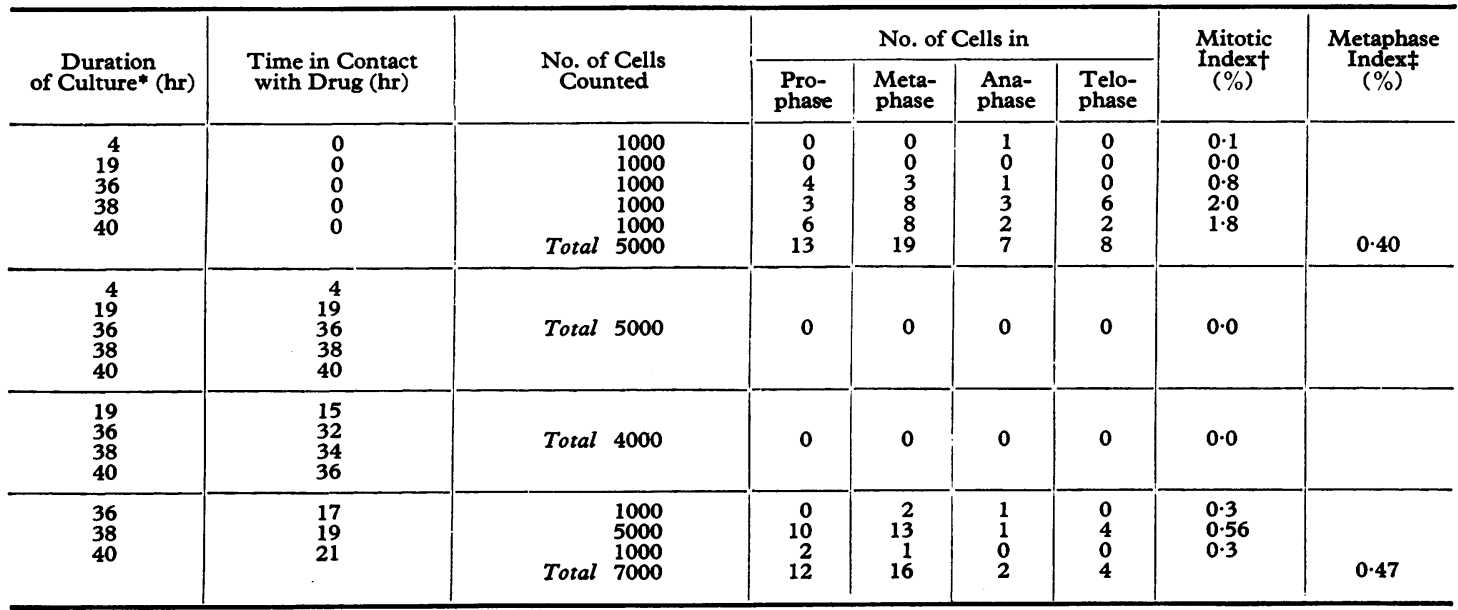

* Time between plating and harvesting cells.

+ Proportion of mitoses among total number of cells.

₹ Proportion of metaphases among total number of mitoses. 
TABLE IV

STAGES IN MITOTIC CYCLE IN INTERPHASE CELLS TREATED WITH $500 \mu \mathrm{g} / \mathrm{ml}$ OF CHLORAMPHENICOL

(drug added at different times after plating)

\begin{tabular}{|c|c|c|c|c|c|c|}
\hline \multirow{2}{*}{$\underset{(\mathrm{hr})}{\text { Duration of Culture* }}$} & \multirow{2}{*}{$\begin{array}{l}\text { Time in Contact } \\
\text { with Drug (hr) }\end{array}$} & \multicolumn{4}{|c|}{ No. of Cells $\dagger$ in } & \multirow{2}{*}{ G2/Total } \\
\hline & & G1 & $\mathbf{S}$ & G2 & Polyploidy & \\
\hline $\begin{array}{r}4 \\
19\end{array}$ & $\begin{array}{l}0 \\
0\end{array}$ & 90 & 3 & 7 & 0 & 0.07 \\
\hline $\begin{array}{l}36 \\
38 \\
40\end{array}$ & $\begin{array}{l}0 \\
0 \\
0\end{array}$ & 115 & 4 & 29 & 2 & $0 \cdot 19$ \\
\hline $\begin{array}{r}4 \\
19\end{array}$ & $\begin{array}{r}4 \\
19\end{array}$ & 86 & 1 & 8 & 5 & 0.08 \\
\hline $\begin{array}{l}36 \\
38 \\
40\end{array}$ & $\begin{array}{l}36 \\
38 \\
40\end{array}$ & 122 & 3 & 23 & 2 & $0 \cdot 15$ \\
\hline 19 & 15 & 44 & 0 & 6 & 0 & 0.12 \\
\hline $\begin{array}{l}36 \\
38 \\
40\end{array}$ & $\begin{array}{l}32 \\
34 \\
36\end{array}$ & 129 & 2 & 17 & 2 & $0 \cdot 11$ \\
\hline $\begin{array}{l}36 \\
38 \\
40\end{array}$ & $\begin{array}{l}17 \\
19 \\
21\end{array}$ & 76 & 8 & 59 & 7 & 0.39 \\
\hline
\end{tabular}

* Time between plating and harvesting cells.

t Fifty cells were measured from each culture; $G 1$ corresponds to $2 \mathrm{C}, \mathrm{G} 2$ to $4 \mathrm{C}, \mathrm{S}$ to intermediate values.

to that in the control culture. An arrest of cells in G2 was not detectable. These results suggest that chloramphenicol needs to be in contact with cells for several hours before it inhibits cell division.

When the effect of chlorimipramine (Tables VII and VIII) is compared with that of chloramphenicol (Tables I and II) several differences become apparent. Firstly, chlorimipramine inhibits cell division at very low concentrations; second, the arrest in metaphase seems to be of longer duration; third, although there is a marked reduction in the number of prophases, with chlorimipramine there is no evidence of an arrest of cells in G2. It would seem that the cells are arrested in G1, bearing in mind that this stage in the control is constantly being added to by the products of mitosis (Table VIII).

Recovery. Cells treated with chloramphenicol showed a considerable ability to recover from its effects. When cells were plated in $1000 \mu \mathrm{g} / \mathrm{ml}$ and left in contact with the drug for $\mathbf{7 2}$ hours and then rescued a proportion of the cells was found to be in DNA synthesis or mitosis after a further period of 48 hours.

TABLE V

NUMBERS OF MITOSES IN CELLS TREATED WITH $500 \mu \mathrm{g} / \mathrm{ml}$ CHLORAMPHENICOL (drug added late in mitotic cycle)

\begin{tabular}{|c|c|c|c|c|c|c|c|c|}
\hline \multirow{2}{*}{$\begin{array}{c}\text { Duration } \\
\text { of Culture* }(\mathrm{hr})\end{array}$} & \multirow{2}{*}{$\begin{array}{l}\text { Time in Contact } \\
\text { with Drug (hr) }\end{array}$} & \multirow{2}{*}{$\begin{array}{l}\text { No. of Cells } \\
\text { Counted }\end{array}$} & \multicolumn{4}{|c|}{ No. of Cells in } & \multirow{2}{*}{ 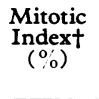 } & \multirow{2}{*}{$\begin{array}{c}\text { Metaphase } \\
\text { Index } \neq \\
(\%)\end{array}$} \\
\hline & & & $\begin{array}{c}\text { Pro- } \\
\text { phase }\end{array}$ & $\begin{array}{l}\text { Meta- } \\
\text { phase }\end{array}$ & $\begin{array}{l}\text { Ana- } \\
\text { phase }\end{array}$ & $\begin{array}{l}\text { Telo- } \\
\text { phase }\end{array}$ & & \\
\hline $\begin{array}{r}5 \\
26\end{array}$ & $\begin{array}{l}0 \\
0\end{array}$ & $\begin{array}{r}2000 \\
2000 \\
\text { Total } 4000\end{array}$ & $\begin{array}{r}6 \\
18 \\
24\end{array}$ & $\begin{array}{l}11 \\
27 \\
38\end{array}$ & $\begin{array}{r}5 \\
5 \\
10\end{array}$ & $\begin{array}{l}3 \\
6 \\
9\end{array}$ & $\begin{array}{l}1 \cdot 2 \\
2 \cdot 8\end{array}$ & 0.47 \\
\hline $\begin{array}{l}28 \\
30 \\
31 \\
33 \\
37\end{array}$ & $\begin{array}{l}0 \\
0 \\
0 \\
0 \\
0\end{array}$ & $\begin{array}{r}2000 \\
2000 \\
2000 \\
2000 \\
2000 \\
\text { Total } 10,000 \\
\end{array}$ & $\begin{array}{r}18 \\
19 \\
8 \\
15 \\
17 \\
77 \\
\end{array}$ & $\begin{array}{r}21 \\
24 \\
9 \\
20 \\
10 \\
84\end{array}$ & $\begin{array}{r}4 \\
6 \\
0 \\
3 \\
3 \\
16 \\
\end{array}$ & $\begin{array}{r}5 \\
25 \\
14 \\
17 \\
9 \\
70\end{array}$ & $\begin{array}{l}2.4 \\
3.7 \\
1.6 \\
2.8 \\
1.8\end{array}$ & 0.34 \\
\hline $\begin{array}{l}28 \\
30 \\
31 \\
33 \\
37\end{array}$ & $\begin{array}{r}2 \\
4 \\
5 \\
7 \\
11\end{array}$ & $\begin{array}{r}2000 \\
2000 \\
2000 \\
2000 \\
2000 \\
\text { Total } 10,000\end{array}$ & $\begin{array}{r}19 \\
11 \\
6 \\
5 \\
2 \\
43\end{array}$ & $\begin{array}{r}30 \\
41 \\
15 \\
17 \\
5 \\
108\end{array}$ & $\begin{array}{l}1 \\
5 \\
0 \\
0 \\
1 \\
7\end{array}$ & $\begin{array}{r}5 \\
27 \\
9 \\
11 \\
7 \\
59\end{array}$ & $\begin{array}{l}2.8 \\
4 \cdot 2 \\
1.5 \\
1.6 \\
0.8\end{array}$ & 0.50 \\
\hline
\end{tabular}

* Time between plating and harvesting cells.

+ Proportion of mitoses among total number of cells.

$\mp$ Proportion of metaphases among total number of mitoses. 
TABLE VI

STAGES IN MITOTIC CYCLE IN INTERPHASE CELLS .TREATED WITH $500 \mu \mathrm{g} / \mathrm{ml}$ CHLORAMPHENICOL (drug added late in mitotic cycle)

\begin{tabular}{|c|c|c|c|c|c|c|}
\hline \multirow{2}{*}{ Duration of Culture* (hr) } & \multirow{2}{*}{$\begin{array}{l}\text { Time in Contact } \\
\text { with Drug (hr) }\end{array}$} & \multicolumn{4}{|c|}{ No. of Cellst in } & \multirow{2}{*}{ G2/Total } \\
\hline & & G1 & $\mathbf{S}$ & G2 & Polyploidy & \\
\hline $\begin{array}{r}5 \\
26\end{array}$ & $\begin{array}{l}0 \\
0\end{array}$ & 79 & 2 & 17 & 2 & 0.02 \\
\hline $\begin{array}{l}28 \\
30 \\
31 \\
33 \\
37\end{array}$ & $\begin{array}{l}\mathbf{0} \\
\mathbf{0} \\
\mathbf{0} \\
\mathbf{0} \\
\mathbf{0}\end{array}$ & 185 & 10 & 51 & 4 & 0.20 \\
\hline $\begin{array}{l}28 \\
30 \\
31 \\
33 \\
37\end{array}$ & $\begin{array}{r}2 \\
4 \\
6 \\
7 \\
11\end{array}$ & 179 & 20 & 51 & 0 & 0.20 \\
\hline
\end{tabular}

* Time between plating and harvesting cells.

† Fifty cells were measured from each culture; G1 corresponds to $2 \mathrm{C}, \mathrm{G} 2$ to $4 \mathrm{C}$, $\mathrm{S}$ to intermediate values.

Oxygen uptake. Trypsinized cells in Hank's solution introduced into the chamber of the oxygen electrode took up oxygen at the rate of $28 \mathrm{nmol}$ $0_{2} / \mathrm{min} / 10^{6}$ cells. When chloramphenicol was introduced to a concentration of $500 \mu \mathrm{g} / \mathrm{ml}$, there was no detectable effect on oxygen uptake. The addition of a further $500 \mu \mathrm{g} / \mathrm{ml}$ of chloramphenicol, making a concentration of $1000 \mu \mathrm{g} / \mathrm{ml}$, also produced no detectable effect. The system continued to take up oxygen at the initial rate until the supply was exhausted. Oxygen uptake was arrested to a large extent when potassium cyanide was added to the cells. This shows that the oxygen uptake in the electrode system is mainly due to mitochondrial respiration. It was concluded that chloramphenicol had no direct inhibitory effect on mitochondrial function.

When cells which had been growing in medium containing $500 \mu \mathrm{g} / \mathrm{ml}$ chloramphenicol were compared with untreated cells, it was found that the untreated cells took up oxygen at the rate of $32 \mathrm{nmol} /$ $\min / 10^{6}$ cells whereas the rate for treated cells was $15 \mathrm{nmol} / \mathrm{min} / 10^{6}$ cells. It was concluded that the inhibition of mitochondrial synthesis by the drug depressed the respiratory rate or, alternatively, thato the respiratory chain has a limited existence and may undergo partial degradation in these conditions. This latter situation has been established in yeast

TABLE VII

NUMBERS OF MITOSES IN CELLS TREATED WITH CHLORIMIPRAMINE

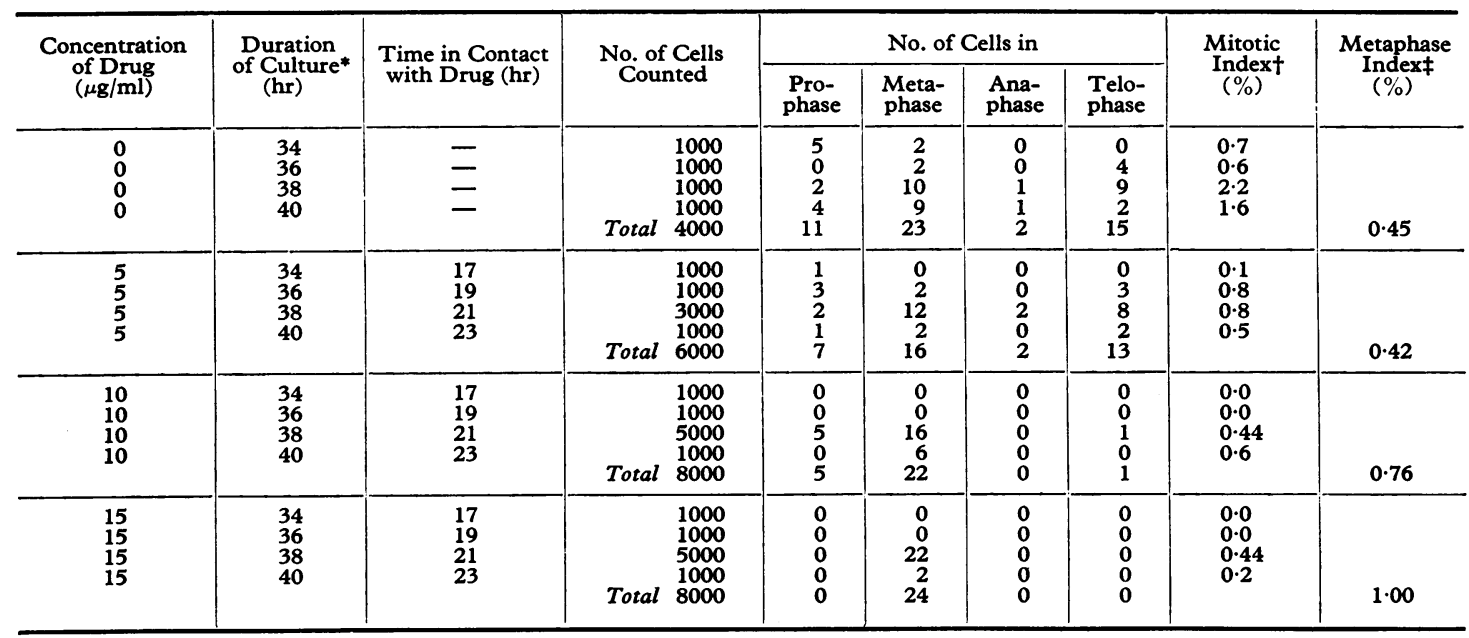

* Time between plating and harvesting cells.

t Proportion of mitoses among total number of cells.

$¥$ Proportion of metaphases among total number of mitoses. 
TABLE VIII

STAGES IN MITOTIC CYCLE IN INTERPHASE CELLS TREATED WITH CHLORIMIPRAMINE

\begin{tabular}{|c|c|c|c|c|c|c|c|}
\hline \multirow{2}{*}{$\begin{array}{l}\text { Concentration of Drug } \\
(\mu \mathrm{g} / \mathrm{ml})\end{array}$} & \multirow{2}{*}{$\begin{array}{l}\text { Duration of } \\
\text { Culture* }^{*}(\mathrm{hr})\end{array}$} & \multirow{2}{*}{$\begin{array}{l}\text { Time in Contact } \\
\text { with Drug }(\mathrm{hr})\end{array}$} & \multicolumn{4}{|c|}{ No. of Cellst in } & \multirow{2}{*}{ G2/Total } \\
\hline & & & G1 & $\mathrm{S}$ & G2 & Polyploidy & \\
\hline 0 & 17 & 0 & 45 & 0 & 5 & 0 & $0 \cdot 10$ \\
\hline $\begin{array}{l}0 \\
0 \\
0 \\
0\end{array}$ & $\begin{array}{l}34 \\
36 \\
38 \\
40 \\
\end{array}$ & $\begin{array}{l}0 \\
0 \\
0 \\
0\end{array}$ & 158 & 9 & 33 & 0 & $0 \cdot 11$ \\
\hline $\begin{array}{l}5 \\
5 \\
5 \\
5\end{array}$ & $\begin{array}{l}34 \\
36 \\
38 \\
40\end{array}$ & $\begin{array}{l}17 \\
19 \\
21 \\
23\end{array}$ & 169 & 10 & 19 & 2 & $0 \cdot 10$ \\
\hline $\begin{array}{l}10 \\
10 \\
10 \\
10\end{array}$ & $\begin{array}{l}34 \\
36 \\
38 \\
40\end{array}$ & $\begin{array}{l}17 \\
19 \\
21 \\
23\end{array}$ & 177 & 6 & 17 & 0 & 0.08 \\
\hline $\begin{array}{l}15 \\
15 \\
15 \\
15\end{array}$ & $\begin{array}{l}34 \\
36 \\
38 \\
40\end{array}$ & $\begin{array}{l}17 \\
19 \\
21 \\
23\end{array}$ & 183 & 3 & 14 & 0 & 0.07 \\
\hline
\end{tabular}

* Time between plating and harvesting cells.

† Fifty cells were measured from each culture; G1 corresponds to $2 \mathrm{C}, \mathrm{G} 2$ to $4 \mathrm{C}, \mathrm{S}$ to intermediate values.

cell mitochondria in the presence of chloramphenicol and erythromycin, when cytochrome oxidase and cytochrome $b$ are lost after about 12 hours (Stone and Wilkie, 1974).

\section{Discussion}

These results provide conclusive evidence that chloramphenicol acts as a mitotic inhibitor in human fibroblasts. Although the most striking effects were obtained with concentrations of 500 $\mu \mathrm{g} / \mathrm{ml}$ and above, the results shown in Table I do not preclude the possibility of some mitotic inhibition with $100 \mu \mathrm{g} / \mathrm{ml}$ of drug or even less. Mitotic metaphase and the $\mathrm{G} 2$ phase preceding mitosis seem to be the two stages which are most sensitive to the drug. Clearly, an arrest of cells in metaphase could tend to increase the mitotic index, while an arrest in G2 would decrease it.

Chlorimipramine also arrests cells in metaphase, but an accumulation of cells in G2 could not be detected with this drug. These findings are in agreement with previous results (Wilkie and Delhanty, 1970; Mittwoch and Wilkie, 1971). Chlorimipramine has a direct effect on oxygen uptake and it would seem that if enough energy is available for DNA synthesis, the cells are able to proceed through G2 until metaphase. By contrast, chloramphenicol affects cellular respiration indirectly.

The fact that no direct effect on oxygen uptake was seen with high concentrations of chloramphenicol indicates that the mitotic inhibition results from arrest of mitochondirial protein synthesis. Since cells treated with chloramphenicol for a long time show a reduced respiratory activity, it seems that synthesis of the respiratory chain is a prerequisite for normal cell division in fibroblasts.

An arrest of cells in metaphase is known to occur from the action of a variety of agents, including colchicine (Hughes, 1952), barbiturates (Caratzali and Roman, 1969), and vinblastine (Baserga, 1969). Other agents, including cycloheximide and mengovirus have been reported to block G2. Recent results by Paton, Silver, and Allison (1974) suggest that a delay in $G 2$ is also seen in fibroblasts from patients with Down's syndrome. This finding is of interest in view of the known association between Down's syndrome and leukaemia. Although the relationship between cause and effect is not understood either in the case of chromosome abnormalities and malignancies nor in toxic drug reactions such as bone marrow dysfunction resulting from the use of chloramphenicol, it seems likely that an undue prolongation of the time taken to complete the mitotic cycle in rapidly growing tissues would interfere with the normal rate of cell proliferation and also lead to imperfect cellular differentiation.

This work was supported by a grant from the Cancer Research Campaign. The integrating microdensitometer was provided by the University of London Central Research Fund.

\section{REFERENCES}

Baserga, R. (1969). In Biochemistry of Cell Division, ed. by $\mathbf{R}$. Baserga, pp. 3-13. Thomas, Springfield, Illinois.

Caratzali, A. and Roman, I. C. (1969). Action stathmocinétique de quelques dérivés barbituriques sur les lymphocytes humain en culture. Compte Rendu Hebdomadaire des Séances de l'Académie des Sciences, Series $D, 268,191-192$.

Grivell, L. A., Reijnders, L., and Vries, H. de (1971). Altered mitochondrial ribosomes in a cytoplasmic mutant of yeast. FEBS Letters, 16, 159-163. 
Harnden, D. G. (1960). A human skin culture technique used for cytological examinations. British fournal of Experimental Patho$\log y, 41,31-37$.

Hughes, A. (1952). The Mitotic Cycle. Butterworths Scientific, London.

Kroon, A. M. and Arendzen, A. J. (1972). The inhibition of mitochondrial biogenesis by antibiotics. In Mitochondria: Biomembranes, pp. 71-83. North Holland, Amsterdam.

Kroon, A. M., Gijzel, W. P., and Nijhoff, W. (1972). The effect of antibiotics on the biogenesis of mitochondria of animals. Atti Seminario di Studi Biologici, 5, 113-122.

Kroon, A. M. and Jansen, R. J. (1968). The effect of low concentrations of chloramphenicol on beating rat-heart cells in tissue culture. Biochimica et Biophysica Acta, 155, 629-632.
Mittwoch, U. and Wilkie, D. (1971). The effect of chlorimipramine on DNA synthesis and mitosis in cultured human cells. British fournal of Experimental Pathology, 52, 186-191.

Paton, G. R., Silver, M., and Allison, A. C. (1974). Comparison of cell cycle time in normal and trisomic cells. Humangenetik, 23, 173-182.

Pisciotta, A. V. (1971). Drug-induced leucopenia and aplastic anemia. Clinical Pharmacology and Therapeutics, 12, 13-43.

Stone, A. B. and Wilkie, D. (1974). Degradation of the respiratory chain in Saccharomyces cerevisiae by erythromycils.

Wilkie, D. and Delhanty, J. D. A. (1970). Effects of chlorimipramine on human cells in tissue culture. British fournal of Exper:mental Pathology, 51, 507-511. 